\title{
INTRODUCTION TO INTELLECTUAL PROPERTY IN THE CONFLICT OF LAWS
}

\begin{tabular}{lrlr}
$\begin{array}{l}\text { INTRODUCTION: INTELLECTUAL PROPERTY IN } \\
\text { THE CONFLICT OF LAWS }\end{array}$ & DEFINITION OF THE PROBLEM & 21 \\
$\begin{array}{l}\text { DELIMITATIONS } \\
\begin{array}{l}\text { THE BERNE CONVENTION AND THE PARIS } \\
\quad\end{array}\end{array}$ & 1 & STRUCTURE OF THE BOOK & 24 \\
$\quad$ CONVENTION & 14 & LAPRÉFACE D'UN LIVRE & 32 \\
\hline
\end{tabular}

\section{INTRODUCTION: INTELLECTUAL PROPERTY IN THE CONFLICT OF LAWS}

Intellectual property and the conflict of larws. Intellectual property in the conflict of laws lies at the intersection of two branches of law: on the one hand, intellectual property law, which concerns the protection of products of the human mind, such as inventions, trade marks and works of literature or art, and on the other hand, the conflict of laws, which concerns the question of which national law is applicable in international cases. Thus, the intersection of these two branches of law concerns the question of which national law is applicable to the protection of intellectual property in international cases. This is the subject of the present study.

For several reasons, this subject is regarded as a thorny issue. For one thing, the $\mathbf{2}$ two sides seem to avoid each other: it is regularly observed that experts in these branches of law have difficulty understanding each other; they speak different languages. ${ }^{1}$ Apparently there is a fault line between the two groups of experts. But, more importantly, the subject is unanimously characterized as terribly complicated, as 'a very difficult domain', ${ }^{2}$ as 'très difficile et très controversée'. ${ }^{3}$

1 Troller 1952, pp. V-VI; De Boer 1993, p. 3; Torremans 2004, p. 104.

2 Torremans 2004, p. 104.

3 Bouche 2002 (Contrefaçon), p. 2999. 
3 Is it really that difficult? Here we stumble upon something peculiar. For people from the nineteenth century, who were the first to be confronted with this subject, it was not difficult at all. They designed the 'principle of national treatment', as it was called, for international intellectual property law. In brief, this principle requires countries to grant foreigners (foreign authors, inventors, et cetera) the same rights as those granted to their own nationals by national law, and they enshrined this principle in treaties that are still in force today. In their view, this principle of national treatment determined in a simple manner, inter alia, which law is applicable to the protection of intellectual property rights. For them, this conflict-of-law aspect of the principle of national treatment was so self-evident, uncontroversial and logical that they paid little attention to it. 'Cela est évident et aucune dérogation n'a été apportée à cette déduction logique', Darras noted in $1887 .{ }^{4}$ And in 1890 Bastide wrote that the principle of national treatment 'résout ce conflit de lois en appliquant la législation du pays d'importation (. . .)', indicating that in the nineteenth century the idea that the principle of national treatment included a conflict-of-law rule was regarded as self-evident.

4 Well, things can certainly change: many failed to come to terms with this conflict-of-law rule in the course of the twentieth century. In 1932 a commentator complained that it is a peculiar conflict-of-law rule, very different from the usual conflict-of-law rules, confusing and inconsistent. ${ }^{6}$ And nowadays it is considered 'heftig umstritten' whether the principle of national treatment contains a conflict-of-law rule at all. ${ }^{7}$ At this juncture it is no longer understood whether and why the principle of national treatment contains a conflict-of-law rule. How is this possible?

5 So we are facing an enigma, the enigma of international intellectual property law: does the principle of national treatment in the nineteenth-century treaties that are still in force contain a conflict-of-law rule? And if so, why do we no longer understand this conflict-of-law rule? Apparently, our subject has become difficult. And apparently, there is another fault line here, a fault line between the past and the present.

4 Darras 1887, p. 606 ('une des conséquences forcées de l'assimilation est de rendre applicables à tout délit les lois du pays de la contrefaçon; cela est évident et aucune dérogation n'a été apportée à cette déduction logique').

5 Bastide 1890, p. 98.

6 Boucher 1932, p. 29 ('étrange, très eloignée des règles habituelles, déconcertante pour les jurisconsultes qui n'y découvrent que contradictions').

7 Von Hoffmann 2001, p. 586, no. 375. 
There lies the challenge and the purpose of this study: to unravel and under- $\mathbf{6}$ stand this enigma; in short, to explain the applicable law at the intersection of the law of conflicts and intellectual property law. ${ }^{8}$

Importance of the study. There is another curious aspect to this subject: the law of conflicts for intellectual property mainly seems to be 'heftig umstritten' in the legal literature but hardly controversial in legal practice. In everyday legal practice the problem is generally left undiscussed and the law of the country for which protection is invoked, the lex loci protectionis, is applied instinctively. Apparently, there is a third fault line here, a fault line between theory and practice. This raises the question whether a study such as the present one is relevant only for the purposes of theory development. The answer to this question is negative. The relative calm in legal practice has passed. Legal practitioners can no longer avoid the question of the applicable law because the hegemony of the lex loci protectionis is increasingly being called into question. In particular, growing globalization and the related rise of the Internet are fuelling the idea that new conflict-of-law rules should be designed for intellectual property law. The hegemony of the lex loci protectionis is increasingly being challenged - challenges that are already reflected in court decisions - and the question of the applicable law has therefore become unavoidable in legal practice as well. '(...) it may be expected that the debate on the applicable law will rapidly gain the attention it deserves', Pertegás Sender noted in $2006 .{ }^{9}$

\section{DELIMITATIONS}

The subject of this study - intellectual property in the conflict of laws - is $\mathbf{8}$ delimited in four respects.

Delimitation 1: applicable law. A first delimitation has just been touched on: 9 this study focuses almost entirely on the law in force (what is the law?) and pays hardly any attention to the desirable law (what should the law be?). The issue of the desirable law will be dealt with only briefly at the end of the study. ${ }^{10}$ The reason for this is that, in my opinion, the debate on the subject at hand is best served by a study that tries to explain the law in force. This is because a great deal has already been written about the desirable law in this field, but to date there has been no satisfactory explanation of the law in force. What is more, a

8 The research question is defined in para. 21 below.

9 Pertegás Sender 2006, p. 247.

10 Section 8.2. 
debate on the desirable law lacks substance until the law in force has been clarified. As Torremans has pointed out, the search for desirable alternatives to the current lex loci protectionis conflict-of-law rule is difficult and risky 'since even the basis for which alternatives are sought is still not very precisely defined'. ${ }^{11}$ This study therefore focuses on this basis - the law in force - bearing in mind Cornish's words: 'One way of reflecting on the best course for the future is to understand the motivating forces of the past. ${ }^{12}$

10 Delimitation 2: intellectual property rights. The second delimitation concerns intellectual property rights. This branch of law comprises two main parts: intellectual property law in the narrow sense (copyright, related rights and database rights) and industrial property law (patents, trade marks, industrial design rights, trade name rights, indications of source and appellations of origin, plant variety rights and topography rights). ${ }^{13}$ It would be going too far to discuss all these rights in this study. The study therefore focuses on the three classical intellectual property rights: copyright, patents and trade marks. They are the oldest and the most important intellectual property rights and have been decisive in the development of the issue at hand.

11 Delimitation 3: conflict of larws. The third delimitation concerns conflict of laws. This branch of law comprises the body of legal rules ('conflict-of-law rules') that indicate which national private law system is to govern international cases. Conflict of laws is one of the three main branches of private international law in the broad sense ('PIL'). The other two main branches are the law of international jurisdiction and the law on the recognition and enforcement of foreign judgments. Generally, these two branches are disregarded - the law of jurisdiction is addressed indirectly. ${ }^{14}$

12 The delimitation with regard to the conflict of laws includes another delimitation, namely a limitation to the private-law protection of intellectual property. Public-law protection, in particular the criminal-law protection of intellectual property, is not specifically addressed in this study, but it is occasionally

11 Torremans 2004, p. 104.

12 Cornish 1996, p. 285.

13 In this study the term 'intellectual property' is defined broadly: it encompasses both intellectual property in the narrow sense and industrial property. Unfair competition (also known as 'unlawful competition', see Van Nispen 2007 (Onrechtmatige daad IV), annotation 1) is not covered by the term 'intellectual property' as used in this study and so it also falls outside the scope of this study. On this subject, see Van Nispen 2007 (Onrechtmatige daad IV), annotations 76-86.

14 This concerns the basis underlying a specific ground of jurisdiction in the field of intellectual property law, namely the exclusive ground of jurisdiction of the court of the State where an industrial property right has been granted; this issue is raised particularly in Chapter 5 and section 8.1.2. 
touched on because in the past no clear distinction was made between privatelaw and public-law protection.

Delimitation 4:protection. The fourth delimitation concerns the aspect of intel13 lectual property law to be dealt with. This study explores only the conflict-oflaw treatment of the protection of intellectual property. ${ }^{15}$ It does not consider the conflict-of-law treatment of other aspects, such as the exploitation (transfer, licensing, et cetera) and inheritance of intellectual property rights.

\section{THE BERNE CONVENTION AND THE PARIS CONVENTION}

Basic conventions. The field thus defined is dominated worldwide by two treaties. As far as copyright is concerned, this is the Berne Convention for the Protection of Literary and Artistic Works of 9 September 1886, as most recently revised on 24 July $1971 .{ }^{16}$ And for industrial property law, this is the Paris Convention for the Protection of Industrial Property of 20 March 1883, as most recently revised on 14 July $1967 .{ }^{17}$ The Contracting States to these conventions form a union for the protection of the intellectual property rights concerned, the 'Berne Union' and the 'Paris Union' respectively. ${ }^{18}$ These treaties have virtually global coverage: by now so many countries have adopted them that they apply in 'virtually all the inhabited territories of the

15 The exact meaning of 'protection' is explored in Chapter 7.

16 Its full title reads as follows: Berne Convention for the Protection of Literary and Artistic Works of September 9, 1886, completed at Paris on May 4, 1896, revised at Berlin on November 13, 1908, completed at Berne on March 20, 1914, revised at Rome on June 2, 1928, at Brussels on June 26, 1948, at Stockholm on July 14, 1967 and at Paris on July 24, 1971, and amended on September 28, 1979 (with Annex), Tractatenblad ['Trb.'] (Dutch Treaty Series). 1972, 157 (see Trb. 2006, 158). Earlier versions of the convention were published in Staatsblad ['Stb.'] (Dutch Bulletin of Acts and Decrees) 1911, 197 and Stb. 1912, 323 (Berlin 1908 version); Stb. 1915, 186 (Protocol to Bern 1914); Stb. 1931, 265 and 361 (Rome 1928 version); and Stb. 1955, 45 (Brussels 1948 version).

17 Its full title reads as follows: Paris Convention for the Protection of Industrial Property of March 20, 1883, revised at Brussels on December 14, 1900, at Washington on June 2, 1911, at The Hague on November 6, 1925, at London on June 2, 1934, at Lisbon on October 31, 1958 and at Stockholm on July 14, 1967, and as amended at Stockholm on September 28, 1979, Trb. 1969, 144; see Trb. 2006, 157. Earlier versions of the convention were published in Stb. 1884, 53 and 189 (Paris 1883 version); Stb. 1902, 177 (Brussels 1900 version); Stb. 1913, 142 (Washington 1911 version); Stb. 1928, 196 (The Hague 1925 version); Stb. I 83 and 539 (London 1934 version); Trb. 1960, 13 and Trb. 1962, 70 (Lisbon 1958 version). Incidentally, the Paris Convention does not apply to all industrial property rights; plant variety rights, for example, are not governed by it (see para. 20 of this Introduction).

18 These Unions are currently administered by the World Intellectual Property Organization ('WIPO'), which was created by the Convention Establishing the World Intellectual Property Organization (OMPI/WIPO), Stockholm 14 July 1967, Trb. 1969, 145, amended on 1 October 2003 (see Trb. 2006, 156); this amendment, however, has not yet entered into force; see also Kamerstukken I and II 2007/08, 31424 (R 1854), A and no. 1. The WIPO is the successor to the earlier Bureaux internationaux réunis pour la protection de la propriété intellectuelle ('BIRPI'), the Bureau of the Berne and the Paris Union. 
globe'. ${ }^{19}$ They are the basic treaties of intellectual property law, cover almost the entire field of intellectual property law, ${ }^{20}$ and within their scope of application they prevail over all other intellectual property treaties. ${ }^{21}$ At the end of the twentieth century their reign was once again confirmed by the Agreement on Trade-Related Aspects of Intellectual Property Rights of 15 April 1994 ('the TRIPS Agreement'), which was agreed within the framework of the World Trade Organization ('WTO'), ${ }^{22}$ since under this TRIPS Agreement, the WTO member countries are under an obligation to observe the substantive provisions of the Berne Convention and the Paris Convention. ${ }^{23}$

15 Thus, we are first confronted with the question whether the Berne Convention and the Paris Convention contain a conflict-of-law rule: if these treaties contain a conflict-of-law rule, that conflict-of-law rule is the law in force at the intersection of intellectual property law and the conflict of laws for virtually the whole world. We will therefore focus on these two treaties.

16 Conflict of laws and aliens law. With the question whether these treaties contain a conflict-of-law rule, we find ourselves - as far as the Berne Convention is concerned - in the midst of a fierce debate on the core provision of that convention, Article 5. That debate is about the conflict of laws and aliens law. What is meant by 'conflict of laws' has just been discussed: this is the body of legal rules ('conflict-of-law rules') that indicate which national private law system is to govern international cases. What should be understood by 'aliens law'? Nowadays we tend to associate aliens law with public law: we think, for

19 Ricketson 2004, p. 219. A list of the member states can be found at the website of the WIPO, <www.wipo. int>.

20 The Berne Convention relates to copyright (Art. 1) and the Paris Convention relates to patents, utility models, industrial design rights, trade marks, trade names, indications of source and appellations of origin as well as to unfair competition (Art. 1(2)). Consequently, related rights, database rights, plant variety rights and topography rights fall outside the substantive scope of these treaties.

21 See Art. 20 Berne Convention and Art. 19 Paris Convention. See e.g. Art. XVII of the Universal Copyright Convention of 6 September 1952 (Trb. 1955, 46), revised at Paris on 24 July 1971, Trb. 1972, 114; see Trb. 1996, 311. This treaty no longer plays a significant part in practice.

22 The TRIPS Agreement is an annex (Annex 1C) to the Convention Establishing the World Intellectual Property Organization, Marrakesh 15 April 1994, Trb. 1994, 235 ('WTO Treaty'); see Trb. 2007, 102. The TRIPS Agreement forms an integral part of the WTO Treaty (Art. II(2) WTO Treaty). For more details on the TRIPS Agreement, see Gervais 2003; Alexander 1993 (particularly p. 18 et seq.). The EC signed the WTO Treaty, of which the TRIPS Agreement is an integral part, and subsequently approved it by Council Decision 94/800/EC of 22 December 1994 (OJEC 1994, L 336/1). As a result, the provisions of the TRIPS Agreement currently form part of the Community legal order (established case law; see, specifically with respect to the TRIPS Agreement: CJEC 11 September 2007, C-431/05, ECLI:EU:C:2007:496; IER 2008/5 (Merck) at 31).

23 See Art. 9 and Art. 2 TRIPS Agreement. Art. 2(2) of the TRIPS Agreement further provides that nothing in Parts I to IV inclusive of the TRIPS Agreement derogates from the existing obligations under (inter alia) the Paris Convention and the Berne Convention. 
example, of the admission of aliens to the territory of a State. But aliens law can also play a part in private law. This private aliens law, which for the sake of brevity is referred to as 'aliens law' in this study, is the body of legal rules that govern the private-law position of aliens in relation to a country's own nationals by either putting them at a disadvantage (discrimination) or putting them on an equal footing or - but this is quite rare - treating them more favourably (reverse discrimination). ${ }^{24}$ These rules may cover a wide range of issues. To give a few examples: in the past foreigners did not have the legal capacity to acquire ownership of immovable property, at least not unconditionally; foreigners were legally unable to be employed as captains on Dutch ships; ${ }^{25}$ and they had to provide security on request when litigating as claimants before the Dutch courts (the cautio iudicatum solvi). ${ }^{26}$ Nowadays non-discrimination of foreigners is self-evident in private law - this is why we usually do not immediately associate aliens law with private law - but it used to be different: once, discrimination against aliens was self-evident in private law too. ${ }^{27}$ It will be clear from the above that aliens law and the conflict of laws relate to different questions. The latter concerns the applicable law, the former concerns the (non-)discrimination of aliens.

Art. 5 Berne Convention. Let us return to Article 5 of the Berne Convention and the debate on the conflict of laws and aliens law in this provision. Article 5(1) to (3) reads as follows:

1. Authors shall enjoy, in respect of works for which they are protected under this Convention, in countries of the Union other than the country of origin, the rights which their respective laws do now or may hereafter grant to their nationals, as well as the rights specially granted by this Convention.

2. The enjoyment and the exercise of these rights shall not be subject to any formality; such enjoyment and such exercise shall be independent of the existence of protection in the country of origin of the work. Consequently, apart from the provisions of this Convention, the extent of protection, as

24 Cf. Kosters and Dubbink 1962, p. 9; Neuhaus 1976 (Grundbegriffe), p. 1; Ulmer 1975, p. 6; Kegel and Schurig 2000, p. 62; Von Bar 2003, pp. 212-218. According to current Dutch views, private aliens law is not part of private international law, but this is not an internationally established doctrine. In France, for example, it is considered part of private international law.

25 Art. 341a (repealed) Wetboek van Koophandel ['WvK'] (Dutch Commercial Code).

26 Art. 152 and 153 (repealed) Wetboek van Burgerlijke Rechtsvordering ['Rv'] (Dutch Code of Civil Procedure). The cautio iudicatum solvi still exists in Dutch law; see Art. $224 \mathrm{Rv}$, which, however, does not contain provisions for foreigners but for all people without a permanent or temporary address in the Netherlands.

27 In addition, private law and public law were not always clearly distinguished in the past. 
well as the means of redress afforded to the author to protect his rights, shall be governed exclusively by the laws of the country where protection is claimed.

3. Protection in the country of origin is governed by domestic law. However, when the author is not a national of the country of origin of the work for which he is protected under this Convention, he shall enjoy in that country the same rights as national authors. ${ }^{28}$

18 These provisions are not easy to understand. Is there a conflict-of-law rule in them? Or is there any aliens law? Specifically, does paragraph 1 - the principle of national treatment - contain a conflict-of-law rule? But what kind of conflict-of-law rule is it? Or does it contain only a principle of nondiscrimination under aliens law, without saying anything about the applicable law? Or does paragraph 2 contain a conflict-of-law rule, given the fact that the second sentence of paragraph 2 refers to the laws of the country where protection is claimed'? Is that a reference to the law of the court seized (the lex fori) or is it a reference to the lex loci protectionis? And does it relate only to the extent of protection and the means of redress? Or does paragraph 3 contain a conflict-of-law rule? Its first sentence refers to the domestic law of the country of origin: is that a unilateral conflict-of-law rule? Or do none of these provisions contain a conflict-of-law rule and do they all relate exclusively to aliens law? Opinions are strongly divided on this matter nowadays. ${ }^{29}$

19 Art. 2 Paris Convention. A similar but less extensive and intense debate is taking place around the core provision of the Paris Convention, Article 2(1), which enshrines the principle of national treatment. Is this a principle of nondiscrimination under aliens law, or does it also contain a conflict-of-law rule? ${ }^{30}$ This provision reads as follows:

1. Nationals of any country of the Union shall, as regards the protection of industrial property, enjoy in all the other countries of the Union the advantages that their respective laws now grant, or may hereafter grant, to nationals; all without prejudice to the rights specially provided for by this Convention. Consequently, they shall have the same protection as the latter, and the same legal remedy against any infringement of their rights,

For the French text, see section 3.4. Paragraph 4 is not included, for ease of comprehension; it contains the definition of the country of origin.

29 A comprehensive overview of current views on this subject is given in section 5.1.1.

30 A comprehensive overview of current views on this subject is given in section 5.1.1. 
provided that the conditions and formalities imposed upon nationals are complied with. ${ }^{31}$

Current debate. The debate on the conflict-of-law content of these fundamental provisions of the Paris Convention and the Berne Convention - an international debate - is difficult and confusing. Opinions are often put forward without any substantiation and inconsistencies are trivialized; besides, parties to the debate sometimes seem to be guided by what they think is a desirable result. There is no convincing interpretation that can explain all parts of these provisions consistently. In short, this is the current state of affairs, which may well be called peculiar when one considers that the nineteenth-century drafters of these treaties apparently took it for granted that their principle of national treatment included a conflict-of-law rule - there again we encounter the enigma of international intellectual property law.

\section{DEFINITION OF THE PROBLEM}

Definition of the problem. Thus, the problem (the central research question) addressed by this study, which, as stated above, aims to explain the law in force at the intersection of the conflict of laws and intellectual property law, can now be defined as follows: do the Berne Convention and the Paris Convention, in particular the principle of national treatment in those treaties, contain a conflict-of-law rule?

Outcome of the study. The study will show that the principle of national treatment in these treaties indeed contains a conflict-of-law rule. It will be shown that this concerns a unique conflict-of-law construction: the principle of national treatment embodies two intertwined rules: a conflict-of-law rule and a principle of non-discrimination. This study will reveal an explanation for this, which, as far as I know, is new.

Importance of history. To understand this dual meaning of the principle of national treatment, we have to understand its genesis. And to understand this history, we have to change our perspective: we will have to adopt a way of thinking about the conflict of laws that is different from our own and enter the world of nineteenth-century statutist conflict of laws. It will be shown that

31 For the French text, see section 4.3. For the sake of clarity, paras 2 and 3 are not included here (see section 4.3). 
from this perspective it is possible to explain the conflict-of-law rule in the principle of national treatment and to provide a sound explanation of all parts of the fundamental treaty provisions cited above. Understanding its history is therefore essential: we will not be able to fathom the principle of national treatment in isolation from its genesis and the world of statutist thought. ${ }^{32}$ History thus reveals why international intellectual property law has 'kein Gegenstück im übrigen IPR'. ${ }^{33}$ In that light, it is remarkable that this essential history has received so little attention to date. This may be due to its complexity.

\section{STRUCTURE OF THE BOOK}

24 Part I: genesis. So we will first delve into the history of the principle of national treatment. This history is long and, as said above, complex. The birth of the principle of national treatment in intellectual property law took place in the early nineteenth century. And the Berne Convention and the Paris Convention, in which the principle of national treatment was enshrined from the very beginning, are also old: the Paris Convention is from 1883, the Berne Convention from 1886. Moreover, both treaties have often been tinkered with in the course of time. They were supplemented or revised at various diplomatic conferences. ${ }^{34}$ These conferences are frequently referred to in this study, which is why they are listed here for the sake of clarity.

- After the founding conferences in Paris in 1880 and 1883, the conferences on the Paris Convention were held in 1886 (Rome), 1890 (Madrid), 1897 and 1900 (Brussels), 1911 (Washington), 1925 (The Hague), 1934 (London), 1958 (Lisbon) and 1967 (Stockholm). ${ }^{35}$

- After the founding conferences in Berne in 1884, 1885 and 1886, the conferences on the Berne Convention were held in 1896 (Paris), 1908

32 Clearly therefore, this study focuses on the principle of national treatment as developed in the context of intellectual property law.

33 Siehr 2002, p. 222.

34 See also notes 16 and 17 to this Introduction. See Sinclair 1984, p. 95 on chains of treaties.

35 The additions adopted by the conferences of 1886 (Rome) and 1890 (Madrid) never entered into force. After 1967 the Paris Convention was amended again on 28 September 1979. For the sake of completeness, the amendments concerned were implemented in accordance with Art. 17 of the Paris Convention and related only to a few administrative provisions (Art. 13(2), under (a)(vi), Art. 13(7), under (a), Art. 14(6) under (a)). The date of entry into force was 3 June 1984 (see Trb. 1980, 31 (Section J) and Paris Notification No. 111 at <www.wipo.int $>$ ). Further, again in accordance with Art. 17, an amendment of Art. 13 and Art. 16 was adopted on 1 October 2003 (see Trb. 2006, 157); this amendment has not yet entered into force, however, see also Kamerstukken I and II 2007/08, 31424 (R 1854), A and no. 1. 
(Berlin), 1914 (Berne), 1928 (Rome), 1948 (Brussels), 1967 (Stockholm) and 1971 (Paris). ${ }^{36}$

The research into the genesis of the principle of national treatment in the Berne Convention and the Paris Convention forms Part I of this study. The purpose of this research is therefore to establish, as objectively as possible, the meaning the drafters intended to give to the principle of national treatment in the Berne and Paris Conventions: what did the drafters of the treaties have in mind? This research shows, as stated above, that the principle of national treatment has a dual meaning: a conflict-of-law rule and a non-discrimination principle.

Part II: present. This conclusion is the point of departure for Part II, which deals with follow-up questions, because such questions inevitably arise. For example: why do we no longer understand the conflict-of-law rule in the principle of national treatment nowadays, while in the past it was apparently regarded as self-evident? And what is the scope of this conflict-of-law rule? Only if we have solved such questions will the mystery of the conflict-of-law rule in the principle of national treatment be fully unravelled.

And there are more far-reaching follow-up questions. Is the conflict-of-law rule that has been found still in keeping with the present time? And if this is not the case, may it be adapted within the limits of the law in force? This is because the interpretation rules of the 1969 Vienna Convention on the Law of Treaties provide that the meaning intended by the drafters, as found in Part I, is indeed the key factor in the interpretation of treaties, even if a few other factors may also be taken into account. ${ }^{37}$ And, beyond the limits of the applicable law: what would be a desirable conflict-of-law rule for intellectual property law? In short: after the examination in Part I of the genesis of the principle of national treatment, an analysis of the contemporary situation regarding this principle is required, in which all these further questions are addressed. This

36 Further, it was amended on 28 September 1979. For the sake of completeness, the amendments concerned were implemented in accordance with Art. 26 of the Berne Convention and related only to a few administrative provisions (Art. 22(2) under (a)(vi), Art. 22(4) under (a), and Art. 23(6) under (a)). The date of entry into force was 19 November 1984 (see Trb. 1980, 39 (Section J) and Berne Notification No. 112 at <www.wipo.int>). Further, again in accordance with Art. 26, an amendment of Art. 22 and Art. 25 was adopted on 1 October 2003 (see Trb. 2006, 158); this amendment has not entered into force, however; see also Kamerstukken I and II 2007/08, 31424 (R 1854), A and no. 1.

37 Vienna Convention on the Law of Treaties, Vienna 23 May 1969, Trb. 1972, 51; see Trb. 1996, 89. This treaty, its interpretation rules and its temporal applicability to the Berne Convention and the Paris Convention are discussed in section 5.3. 
analysis, which leads to a reformulation and reform of the core provisions of these treaties, constitutes Part II of this study.

28 Basic plan. This leads to the following basic plan for this study:

Part I. Genesis of the principle of national treatment

Chapter 1. The birth of the principle of national treatment in copyright law.

Chapter 2. The Berne principle of national treatment: the genesis of Article 5(1).

Chapter 3. The perfection of the Berne principle of national treatment: the genesis of Article 5(2) and (3).

Chapter 4. The genesis of the principle of national treatment in the Paris Convention.

Part II. The principle of national treatment today

Chapter 5. The conflict-of-law rule in the principle of national treatment.

Chapter 6. The aliens-law rule in the principle of national treatment.

Chapter 7. The scope of the principle of national treatment.

Chapter 8. Reformulation and reform.

29 Copyright and industrial property. As already shown by this basic plan, the focus of research will be on copyright. In our research field, the issues for copyright and industrial property law are virtually the same, but for various reasons the copyright context is more complex and controversial. That is why we will focus on copyright law and view industrial property law in terms of the question of how similar or different it is from copyright law. ${ }^{38}$ If we have solved the more difficult question, the easier one will fall into place.

30 Sources. The research for this study was carried out on the basis of an analysis of a multitude of available text sources - sources from the nineteenth, twentieth and twenty-first centuries. These sources include in particular the 'travaux préparatoires' of the Berne Convention and of the Paris Convention (the 'Actes'), ${ }^{39}$ other nineteenth-century treaties on the protection of intellectual

38 This approach has been developed along different lines in this study. The history of the development of the principle of national treatment, which is examined in Part I, is complex and this is why, for the sake of clarity, copyright law and industrial property law are discussed successively in that part: Chapters 1-3 are devoted to copyright law and Chapter 4 is devoted to industrial property law. In Part II, there is no need for this separate treatment for the sake of clarity, which means that in this part copyright law and industrial property law are dealt with on a parallel basis (with the emphasis on copyright law, as stated above).

39 In this context, travaux préparatoires means the official publications (usually called 'Actes de la Conférence') of the Bureaus of the Berne and Paris unions (later the WIPO) of the documents relating to the diplomatic conferences about these treaties. This includes conference documents such as proposals, minutes and reports of meetings, speeches, commission reports, etc. Some of the travaux préparatoires of the Berne Convention 
property, national intellectual property laws, case law of superior courts in particular, literature, publications of the Bureaus of the Unions, ${ }^{40}$ resolutions, conference reports and proceedings. Almost exclusively, primary sources were used. In addition, sources from various treaty countries were used, as this concerns an international debate on multilateral treaties. ${ }^{41}$ Naturally, it is necessary to make a restriction in this respect: the emphasis lies therefore on countries that played a leading role in the field of research involved, particularly during the decisive period: France and Germany. ${ }^{42}$

Basic concepts. In this field of research there is a lack of established terminology on a number of important points. As far as possible, this study has used generally accepted definitions. Where such definitions are lacking, an attempt has been made to define the definition chosen as clearly as possible. Occasionally, a new definition of the author's own making is introduced; this is then mentioned. For the sake of clarity, a list of basic concepts is included at the end of this study (see Glossary).

\section{LA PRÉFACE D'UN LIVRE}

La préface d'un livre. This concludes the introduction to this book, which was closed on 1 January 2009. Finally, let us move back in time for a moment to Paris, 4 November 1880. The Palais du Quai d'Orsay, which houses the Ministry of Foreign Affairs, is the venue for the international conference that will draft the Paris Convention. The president of the conference, the French senator Bozérian, delivers his opening address to the delegates. He compares the treaty to be drawn up with a book, which will be opened

were recently published on the Internet, namely on the associated website at Ricketson and Ginsburg 2006 (<www https://global.oup.com/booksites/content/9780198259466/>, see Ricketson and Ginsburg 2006, p. xix). This has improved accessibility of the travaux préparatoires, but - unfortunately - only (unofficial) English translations were published. For this study on the other hand, the original French texts were used and reference is made to the original official publications ('Actes') of the Bureaus of the Berne and Paris Union (later the WIPO); see also note 42 of this Introduction.

40 This concerns, inter alia, publications of the Bureaus of the Berne and the Paris Unions in their official bodies, Le Droit d'Auteur ('DdA') and La Propriété Industrielle ('PI') respectively.

41 Not much literature on this subject has been published in the Netherlands either; see in particular De Boer 1977, Van Eechoud 2003 and Van Engelen 2007. Case law, particularly from the superior courts, is also scarce in the Netherlands.

42 Quotations will, for reasons of verifiability, be given in their original language as far as possible. The French language plays a key role in this, if only because the French text of the treaties is the decisive authentic text. See Art. 29(1) of the Paris Convention and Art. 37(1) of the Berne Convention (which was incorporated into the Convention in 1948; until then, the French text had been the only authentic text of the Berne Convention, see Ricketson and Ginsburg 2006, p. 187; Röthlisberger 1906, p. 42). 
and will hopefully not be closed for a long time; and he compares the work of the delegates with writing the introduction to that book: 'C'est la préface d'un livre qui va s'ouvrir et qui ne sera peut-être fermé que dans de longues années. $^{2} 3$

33 Indeed, the book they began to write is still not closed after all these years: the Paris Convention and the Berne Convention are still in force. Yet, since we no longer understand the principle of national treatment today, it is a closed book for us. Let us start reading that open-yet-closed book.

Update. The Dutch-language original was completed on 1 January 2009. This translation, however, also includes updates, as mentioned in the Foreword. These have taken the form of separate, indented paragraphs headed 'Update', which have been inserted where necessary. Updates are limited to the most significant case law and legislation up to 1 May 2021.

43 Actes PC 1880, p. 18-19 (Procès-verbaux, opening speech by the President Bozérian). 